\title{
Social Norms and Impediments of Women Development in Bangladesh
}

\author{
Abul Kalam \\ Lecturer in Sociology, Department of Economics, Bangladesh University of Business and Technology \\ (BUBT)Mirpur-2, Dhaka, Bangladesh \\ Correspondence: Md. KALAM, 32-44 Steinway Astoria, NY11103, United States.
}

\author{
Received: January 11, 2014 Accepted: February 17, 2014 Available online: March 3, 2014 \\ doi:10.11114/ijsss.v2i2.365 \\ URL: http://dx.doi.org/10.11114/ijsss.v2i2.365
}

\begin{abstract}
This study focuses upon the contemporary process of Social Norms and Impediments of Women Development in Bangladesh. The development of women in organizations, Decision making, Political participation and gender mainstreaming is currently seen as the dominant conceptual model for promoting social justice and women equality. This study intends to see the position of women, discourses and various political, economic and social factors that surrounded these events. The impediments of women in Bangladesh were being pulled in different directions as a result, the context of social norms and gender inequality that existed at global, national, community and domestic levels. Child marriage is one of the main impediments of women empowerment and implementation of the government's vision-2021. In Bangladesh, the patriarchal capitalism puts women in such a position within their communities that they always remain subordinate under male domination and in many cases this is reflected through violence (Hadi, 2009).
\end{abstract}

Keywords: Impediments, dowry, Social Norms, Violence, Empowerment, Freedom of Choice

\section{Introduction}

Social norms are related to human behavior, attitude, and ethics. It is indicate the notions of society about what is good or bad. Most of the society is male dominating society as a result women are in vulnerable situation. Since the beginning of human civilization patriarchal societies males are emancipated and female are seeking equal of rights but social norm towards female suppression. Every step towards women equality is a struggle against of social norms. Bangladesh is a poor developing country in South Asia. Half of the total populations are women. Over all developments cannot be achieved without women participations and involvement in the development sectors of the country. But at the beginning of civilization the first agriculture and pastoralist society established by women. Long historical background of women development is exploitation by male. Women participation in socio-economic activities as well as decision making, political rights, human rights, decision making, access to properties, freedom of choice, freedom of speech everything are essential for women development but social norms are the main impediments of women development. Violence against women in Bangladesh is a very common practice which denies women's equal opportunity, security, self-esteem, and dignity in the family and in the society as an entire. Because most of the people in Bangladesh are Muslims as a result religious values and social traditions strictly prohibited women to go through out of social norms. That is why social norms are impediments of women development in Bangladesh. However, Bangladesh Government has recently passed the domestic violence (Prevention and Protection) Act of 2010 for the protection of women and children from family violence and discrimination. According to constitutions of Bangladesh "all citizens are equal before law and are entitled to equal protection of the law (Article 27 of the Constitution), The state shall not discriminate against any citizen on the grounds of religion, race, caste, sex or place of birth (Article 28(1), Women have equal rights with men in all spheres of the state and public life (Article 28(2).

\section{Literature Review}

According to UNICEF 2008, includes different forms of abuse and exploitation in defining domestic violence perpetrated by intimate partners and other family members "Physical abuse such as slapping, beating, arm twisting, stabbing, strangling, burning, choking, kicking, threats with an object or weapon, and murder. It also includes traditional practices harmful to women such as female genital mutilation in African society or honor killings as well as sexual abuse such as coerced sex through threats, intimidation or physical force, forcing unwanted sexual acts or forcing sex with others.

Kabeer, 1994 in her book Reversed Realities: Gender Hierarchies in Development Thought, examines the biases which 
underpin mainstream development thought, and which account for the marginal status given to women's needs and interests in current development policy. She argues that despite global gender concern women continue to occupy a marginal place in development thought and policy, and that the institutions within which development policies are made and implemented are male biased.

Centre for Policy Dialogue (CPD), 2009 Observed that domestic violence, i.e. physical, psychological, economic and sexual abuse and violence are prevalent throughout Bangladesh. Most of the victims 93 percent reported that they had experienced physical violence; only 13 percent having experience of sexual violence 91 percent victims reported that they had experienced economic violence and 84 percent victim psychological violence committed by their husbands.

Zaman, 1999 in Bangladesh women faces various forms of violence ranging from wife abuse to rape, dowry killings, acid throwing, sexual harassment, and sexual slavery through trafficking”. Women's life expectancy has increased by 15 to 20 years in developing countries; more women have joined the labor force, thus narrowing the gender gap in employment and in wages (World Bank, 2001). The reduction in fertility and higher use of contraceptive methods in many developing countries has both lowered maternal mortality and eased the burden of unpaid care work which usually falls upon women and girls; the presence of women in politics has also grown in most countries (Molyneux and Raravi, 2006).

The violence against women in Bangladesh is occurs into different levels such as the family, community and country level another some forms of gender based violence at family and community levels may be tacitly approved and promoted through state laws and institutions by existing patriarchal social norms. Social norms are typically seen to emerge in environments characterized by multiple equilibriums, to keep the community in a preferred equilibrium Kandori, 1992. Women have exist some social barrier like criminalizing particular forms of violence against women, such as rape and domestic violence, these may be largely ineffectual and barely enforced, largely because much violence against women takes place in the domestic sphere, where customary, personal or family laws often prevail, and state institutions are reluctant to intervene Schuler, 1992; Pisa and El-Bushra, 1992. Whilst the physical dimension of gender violence may be the most readily identifiable, psychological abuse, the deprivation of resources for physical and psychological needs, and the commodification of women, through trafficking and prostitution, are also important dimensions of gender violence. Schuler, 1992

Postmus, 2000 (cited in Johnson, 2008) argue that domestic violence is a pattern of behavior in a relationships by which the batterer attempts to control victim through a variety of policy ... . These policies may include fear and intimidation any kind of abuse, destruction of property and pets, isolation and imprisonment, economic abuse, and rigid expectations of sex roles. Social norms and religious values is a major social problem of women development in Bangladesh. Women are economically vulnerable situation within the family to maltreatment and abuse by husbands, in-laws, and other family members. In 2007 research study shown that more than half of married women aged 15-49 reported that they had experienced some form of physical and sexual violence from their husbands. Bangladesh is a suitable place for women and child trafficking because of poor economic condition. Adults are also trafficked internally for using commercial sex worker and sexual exploitation. Children are sold into bondage by their parents most of them are induced into commercial sexual exploitation and physical coercion. In some context especially in Chittagong division young boys are forced to prostitution. Women and child trafficking occurs from more rural regions to cities for the causes of poverty. Internationally, from Bangladesh women and children are trafficked to Middle East, India and Pakistan for using commercial sex worker or forced labor. Many brothel owners and pimps compel Bangladeshi girls to take steroids to make them more attractive to clients. There are 90 percent of girls and women between the ages of 15 and 35 in Bangladeshi brothels they are drug addicted.

In Bangladesh Rape are common forms of violence against women. Bengalis culture holds woman's chastity sacred but rape crimes are particularly damaging to woman's self-identity and social future as well as physical and psychological wellbeing. The growing rate of rape crimes is an alarming phenomenon of withdrawing women value in society. Men not only rape women but also physically torture and murder as well. The last few years gang rape has become the widespread form of rape in Bangladesh. It is being normalized in the young male community.

Bhuiya et.al, 2003 Reported that the most frequently mentioned reasons for verbal abuse included wife's questioning of the husband on day to day affairs 29.1 percent followed by failure of the wife to perform household work satisfactorily. Another 17.6 percent reported economic hardship of the family, 11.5 percent failure of the wife to take proper care of the children, 10 percent not wearing the veil or conforming to other expected behavior, 5.5 percent inability to bring money from the natal home, 3 percent not taking good care of Brother \& Sister in in-laws and relatives. The rest of the 2 percent reasons included supporting the natal home, failure to have children, having too many children, dark complexion of children, family feud between the husband's family and natal family and suspected relation with others. Similarly, the most frequently mentioned reasons for physical abuse included questioning of the husband 29.9 percent failure to perform household work satisfactorily 18.8 percent economic problems 9.4 percent failure to take care of 
children properly 5.1 percent stealing 3.4 percent refusal to bring dowry from natal home.

Jahan, 1994 reported that family quarrel was the reason given by most of the women as the cause of violence. Family quarrel was referred to as a value term that included many specific reasons such as husband's dissatisfaction over wife's management of expenses, housekeeping and child care, jealousy and suspicious nature, exaggerated sense of superiority over a wife as reflected in household decision making, sexual maladjustment and such. The reasons for discord were found to be exacerbated by stress resulting from prolonged illness in the family, sudden financial loss, loss of job and aggravation by in-laws. Non-payment of dowry was the next most important cause mentioned for violence.

Ahmed, 2005 and Bhuyia et al. 2003 their studies show that 66.8 percent women were vulnerable to abusive words against them and their parents by their husbands and most of the women were physically abused by their husbands and were seriously injured to consult a healthcare provider. Physical abuse or wife beating by their husbands is almost a universal form of domestic violence against women. Worldwide 10-70 percent of women found being physically violated by their intimate partners in their lives.

Moghadam, 1994 shows that the nation is an extended family writ large then women's role is to carry out the tasks of nurturance and reproduction. If the nation is defined as a religious entity, then the appropriate models of womanhood are to be found in scripture. Nationhood has been recast in these terns in the latter part of the twentieth century, and this has distinct implications for feminism as an emancipatory project. Women become the revered objects of the collective act of redemption, and the role models for the new nationalist patriarchal family.

Zaman, 1999 in his study reported that patrilineal inheritance and ownership system in Bangladesh perpetuating the male domination in interpersonal and social relationships which trigger and perpetuate the abuse of women. This unequal property right of women ultimately results in discrimination and exploitation in nearly all aspects of life which is legitimized and reinforced by the existing socioeconomic system and increases women's powerlessness and vulnerability to the male member of the family which causes domestic violence for life long.

Ahmed, 2005, Koenig et al, 2003, Morrison et al, 2007, Naved and Persson, 2005 in their study reported that in Bangladesh, marital violence against women is also linked to women's individual attributes like age, education, economic autonomy, empowerment, previous victimization and history of violence in parental family. Partner's attributes includes age, education, employment, use of alcohol and drugs, history of violence in parental family, level of communication with her. The social factors are level of economic inequality between men and women, level of female autonomy, attitudes towards gender roles and violence against women, the extent of extended family, neighbors' and friend's intervention in domestic violence incidents and some measure of social capital.

World Bank, 1995 reported that while women's unpaid, reproductive work is vital for household welfare and for regeneration of the labor force, socially defined inequality in intra household division of labor makes women's entry and productivity in the labor market difficult. Kabeer, 2003 in his study shows that women's participation in market employment has been historically constrained due to their traditional gender roles requiring them to shoulder the main responsibility of household work on a daily and generational basis. Koenig et al, 2003 reported that women from all socio-economic strata but explored factors associated with abuse of women by the husband and in laws. However, the time period for abuse was not explicitly specified in this study. They reported that 42 percent of the violence was perpetrated by the husband or the in laws.

UNRISD, 2005 reported that gender equity is unlikely to be achieved unless women command greater influence over affairs of the state and change the culture, practice and outcomes of politics to respond better to gender equality concerns. World Bank 2001 shows that although over the years there has been heightened presence of women in politics in no developing region do women hold more than 8 percent of ministerial positions in government. WB also shows that in industrial countries women in the formal sector earn an average of 77 percent of what men earn while in developing countries this figure is 73 percent. As only about a fifth of the wage gap can be explained by gender differences in education, work experience, or job characteristics, this shows that gender discrimination exists in labor markets all over the world.

Molyneux and Razavi, 2006 show that women have had to bear the brunt of structural adjustments being shock absorbers and care-givers of last resort. As social safety nets are virtually absent in developing countries, under free market conditions poor women have had to "scramble for cash" by working on exploitive terms.

Roy 1992 noted in his study carried out by the Bangladesh Rural Advancement Committee (BRAC) in Jamalpur, that most women who are beaten suffer from beatings every week which are severe enough to .leave marks on the body and cause pain for several days. Such beatings may be related to dowry, to the perceived failure of a woman, particularly a wife to fulfill her household duties or to be properly humble and obedient or they may serve as an outlet for male frustration. Numerous commentators have remarked on beating as a punishment for failing to do the husband's bidding.

Moghadam, 1994:4 argued that if the nation is an extended family writ large, then women's role is to carry out the tasks 
of nurturance and reproduction. If the nation is defined as a religious entity, then the appropriate models of womanhood are to be found in scripture. Nationhood has been recast in these terns in the latter part of the twentieth century and this has distinct implications for feminism as an emancipator project. Women become the revered objects of the collective act of redemption, and the role models for the new nationalist patriarchal family.

There is a dramatic shift of women's like that employment, participation in training programs and increased education, access to and use of credit and greater visibility in social and political life have made both rural and urban women more visible than ever before and have enabled them to negotiate for control of resources heretofore unavailable to them. These shifts highlighted that changing space and physical presence of women as they come to share resources and places. Women as an independent subject to decisions making and frame demands that challenge previous forms of labor control and subservience. The new areas of participation focus attention on women's bodies and their new public role as a site for contesting previous and new social relations and forms of production, power and patronage Feldman, 2001:36.

Most of the women`s mobility in Bangladesh has increased into different reasons. Many women`s moved from secluded context of household production to wage labor in the formal and informal economy due to broader socioeconomic changes. Since 1980s, thousands of rural women have been recruited in the labor force for the rapidly increasing garments industry. There are an estimated 1.4 million workers; their 80 to 90 percent are women and young girls are working in the garment industries in Bangladesh Siddiqi, 2000:12. A growing number of men went abroad to in the Middle East countries and elsewhere to work as migrant laborers women were also more visible in places like banks withdrawing money sent to them. Government resources to rural women designed to generate employment and improve women's literacy and health care also increasing significantly. Other donor based NGOs emphasizing the incorporation of Woman in Development (WID) strategy started targeting women in their programs, thus making more women visible in new contexts. All such shifting challenged to established patriarchal norms associated with women's seclusion and unpaid housework.

Jahan, 1989 shows that macro policies, major programs and projects generally overlook men's and women's differentiated roles in development; yet their impact in changing gender roles and status is far greater than that of women specific mandates and projects. Plans and resource allocation patterns generally ignore women's productive roles. Project assistance by donors highlights women's reproductive roles in the narrow context of controlling women's fertility. The special machineries created to advocate women's equal participation remain institutionally weak.

Mitra, 2003 shows that the establishment size is negatively related to gender equality although women working on higher managerial posts earn more in large organizations than smaller ones; still the gender wage gap significantly favors of men in large establishments despite controlling for worker and human capital characteristics. Resolving the controversy, Bloom et al, 2006 concluded that whatever may be the size, purpose or structure of an organization only a well managed organization i.e. an organization where planning, co-ordination, monitoring and leadership is effective offers a work conducive as well as family friendly environment for women.

Commonwealth Secretariat, 1999 on practical level human resource managers in formal organizations may face the following limitations in creating a gender equitable environment;

- Difficulty in realizing targets for women in decision making positions due to lack of suitable candidates

- $\quad$ Problem in identifying and eliminating gender based discrimination in matters of appointments, promotions, pay, conditions of employment and disciplinary procedures

- Convincing managers and decision makers in the public sector to allow their staff to participate in gender awareness training

- Insufficient budgetary allocation for setting up institutional structures for the promotion, implementation and monitoring of gender reform programs

- Challenges in monitoring, reporting and improving systems dealing with sensitive gender issues such as work place sexual harassment

- $\quad$ Lack of incentives for encouraging implementation of plans for gender equality in different organizations.

Helie Lucas, 1994:396 argued that during the past two decades and more especially during the last one, Muslim Personal Laws have been at the center of Muslim identities; new Muslim Personal Laws have been passed, reinforced, or modified in ways which are highly unfavorable to women. This phenomenon could be interpreted as the expression of the power of fundamentalists, and as the collusion of states with fundamentalist movements. No matter whether fundamentalists are in power or in the position of a powerful main opposition party, or whether they are just growing, in most cases, their claim to an "Islamic" private sphere through the adoption of personal laws is very generally heard by those in power. 
Traditional family background of women, this is strongly discouraged of political empowerment. Male domination of formal political structure is another factor that hindered women political empowerment Bari, 2005. In addition to this the socio-cultural dependency of women is one of the key factors to their political participation in public political domain Connell, 1987.Women economic dependency and lack of access to ownership of productive resources limiting the scope of their political work Eisenstein, 1984 as like supported by Naz \& Rehman, 2011:65. In addition of patriarchy is household, social, ideological, political system in which man by force, direct pressure or through rituals, tradition, law, language, custom etiquette, education, and the division of labor, determine the rule of female is everywhere subsumed under the male Sarho, 1997.

Women entrepreneurs in Bangladesh also suffer from the myth of women not being effective organizers and best suited for housekeeping Matiur Rahman, Bhattacharjee and Lahiri, 1998. This has created difficulties for women to become true entrepreneurs. In another study on women entrepreneurs in Bangladesh, Anwar, 1992 found that due to the prevailing social norms, women entrepreneurs were prevented from managing their businesses independently. These norms had restricted women entrepreneurs' mobility, and thereby affected interaction with others.

\section{Methodology}

Methodology is a mode of inquiry of data that attempts to systematically measure and predict phenomena of numbers, percentage and analysis. Data measurement ensure regarding beliefs, attribute, feelings and opinions about the target population. This study is attempt to understanding about the social Norms and Impediments of Women Development in Bangladesh particularly at Narsingdi district. This study site was conducted at Shibpur, Upazila in relation to two selected union porishod name Jossar union and Joynagor union. These two unions selected for my study because of most vulnerable situation of women empowerment. Where actual population is 23565 both male and female, data has been collected through structured-interview schedule from 200 female respondents. Age limit of respondent's was 18 and above. This study used quantitative methodology data sources into different journals, article, and newspaper. This chapter including sample size, study population, process of data collection will be explain to gain an insight about the whole procedure of this research paper.

\section{Results Analysis}

Results analysis of the study has been prepared under various indicators of women development to the related of research topic

\subsection{Social Impediments to Women's Political Empowerment}

Women's political participation is one of the vital factors that strongly obstruct women political empowerment in Bangladesh as well as globally. The social impediments boundaries between public and private sector women politics treated negatively. Although, the gender role ideology is not static rather remain in unrest while intersecting with economic, social and political systems of a particular society in Bangladesh.

Table 4.1 Social Impediments to Women's Political Empowerment

\begin{tabular}{lll}
\hline Social Impediments & No. of Respondents & Percentage \\
\hline Traditional Social Structure & 29 & 14.5 \\
Stereotype Image of Women & 21 & 10.5 \\
Gender Segregation & 29 & 14.5 \\
Religious Misinterpretation of Women & 32 & 16.0 \\
Illiteracy and Ignorance & 28 & 14.0 \\
Women are for domestic tasks & 35 & 17.5 \\
Strict Purdha Protha & 26 & 13.0 \\
Total & 200 & 100.0 \\
\hline
\end{tabular}

The table 4.1 shows that 14.5 percent respondents said traditional social structure strongly discourages women's political empowerment, another 10.5 percent respondents argue that stereotypical or predetermined images in the mind of women especially in Narsingdi belt also restrict women's political empowerment. In addition to this, 14.5 percent data correlates gender segregation as of one of the impediments. In this context, 16 percent data shows that religious misinterpretations of women in development process. Because women are not enough intelligent like male, where traditional religious knowledge also obstructed women's political empowerment. In such a run, illiteracy and ignorance of women folk regarding their rights and duties in relation to politics hinder women's political empowerment. As the data reveals which is collected from respondents 14 percent said that politics is a commercialized game which needs money as well as economic resources. Another 17.5 percent data shows that women's are only restricted to their houses and appoint with domestic tasks which negatively affect on women political empowerment. In Bangladesh ruralculture is unconditionally based on customary laws while rural women follow their tradition and never turn from the existing order and social norms. In this regard, Purdah Protha is one of the prevalent norms in area where deviation from these 
norms create further complexities of security measures and problems. Further, 13 percent data highlights strict Purdah Protha as well as security problems in regard of rural women have negative impacts on women's political empowerment in Bangladesh.

\subsection{Patriarchal Social Systems and Women's Empowerment}

Patriarchy is a male dominating social system where male determined women access of society. It is transforming male and female into man and women construct the hierarchy of gender relation. Patriarchy is the norms practiced in Bangladesh which is influenced all other social, political dimension of women life.

Table 4.2 Patriarchy and Women's Political Empowerment

\begin{tabular}{lll}
\hline Patriarchy and Women's Political Empowerment & No.of Respondents & Percentage \\
\hline Women have no Economic Power & 33 & 16.5 \\
Males Superiority Over Women & 47 & 23.5 \\
Males Hold Over Decision Making Process & 31 & 15.5 \\
Women are Consider as a Second Class Citizen & 22 & 11.0 \\
Women are for Home or for Grave & 33 & 16.5 \\
Women Dependency over Men & 15 & 7.5 \\
Feudalism & 19 & 9.5 \\
Total & 200 & 100 \\
\hline
\end{tabular}

The table 4.2 shows that 16.5 percent women have no power to take initiative of economical activities because economical power is best suited to man instead of women. Another 23.5 percent respondents said that in patriarchal structure man is more superior instead of women in politics. On the other hand 15.5 percent respondents said that decision relating to her carrier, selection of life partner, vote casting, political affiliation and contesting of elections as well as political demonstration is man oriented in nature. 11 percent data shows that women in Bangladesh especially study area are considered as like second class citizens and not enjoying the same status as like as men. In addition to this 16.5 percent represents that women role and status is confined to domestic activities and they are not allowed to public sphere to participate in political activities. In this regard 7.5 percent and 9 percent respondents express that feudalistic nature of society influence women empowerment in rural society of Narsingdi district.

\subsection{Economic Impediments and Women 's Development}

Women economic development promote women's economic rights and independence including access to employment appropriate working conditions and control over economic resources facilitate women's equal access to resources, employment, markets and trade provide business services, training and access to markets, information and technology, particularly to low-income women strengthen women's economic capacity and commercial networks to improve economic development. But some impediments stopped women open economic access. Several studies in Bangladesh also around the world carried out the challenges faced by women entrepreneurs. The three major stages in the entrepreneurial process creating, nurturing and nourishing are the same for men and women. Some problems faced by women which are different dimensions and magnitudes due to social and cultural reasons. The gender discrimination in many societies impact the sphere of women in industry and a cumulative effect of psychological, social, economic and educational factors act as impediments to women entrepreneurs entering the mainstream of development.

Table 4.3 Economic Impediments and Women Development

\begin{tabular}{|c|c|c|}
\hline Economic Impediments and Women Development & No. of Respondents & Percentage \\
\hline Access to employment & 46 & 23 \\
\hline Access to infrastructure & 21 & 10.5 \\
\hline Access to Proper Training & 34 & 17 \\
\hline Access to Finance & 37 & 18.5 \\
\hline Access to information and technology & 32 & 16 \\
\hline Access to markets & 30 & 15 \\
\hline Total & 200 & 100 \\
\hline
\end{tabular}

Here the table 4.3 shows that, 23 percent respondents have no access to employment but women employment is a key issue for women development. 10.5 percent respondents have no access to business infrastructure. But women needed for reliable physical infrastructure like that road transportation, air transportation and predicable trade support infrastructure like knowledgeable bureaucracy, supportive government mechanisms etc. 17 percent data shows that women have very limited access to vocational and technical training about business. 18.5 percent data shows that women have limited access to financial support to start proper business. Accessing credit particularly for starting business enterprise financing is one of the major constraints faced by women entrepreneurs. 16 percent data shows that women have little access to proper business information and technological support. But they needed for reliable 
telephone exchange and Internet service Potential for E-commerce and E-trade, access to electronic banking and transfers use of English as the media of communication through the Internet services.

\section{Discussion}

Gender discrimination is a comprehensive issue that is not confined to the boundaries of a particular country. In the world context women perform more than three quarters of the total work included to their household work. So women contribution is a significant of total workforce but their payment is very poor. According to some statistics, women receive only one-tenth of the world's income and one-hundredth of its property rights. Women face various impediments every day by the hands of people whom they share their lives. Violence against women in Bangladesh has risen to terrible levels. The Constitution of Bangladesh states that women have equal rights balance with men in all spheres of daily life. It also recognizes religious personal laws, which are unequal to women. According to the constitution of Bangladesh, the State takes responsibility to ensure equality among all citizens and maintain gender equality. But state does not ensure gender equality where personal laws are based on Islamic religious and social values systems. As a result both Muslim and non-Muslim women faced gender discrimination under their personal laws. In Bangladesh women also discriminated into different ethnic, race \& gender dimension. Current research shows that the status of women in family, society, workplace, education and health are lower position than male position. Some women and gender related terminology given below;

\subsection{Definition of Gender}

The term "gender" refers to the social roles and relations of the sexes. It is applied to a entire range of society and institutions from traditional anthropological concerns such as family, marriage and kinship to the market, to religion and the state. The concept "gender" helps us look at the ideological constructs as well as everyday practices that express, reproduce, and sustain unequal distribution of power, prestige and resources between boys and girls also between men and women in various spheres of our society. Flax, 1987 noted that "From the perspective of social relations, men and women are both prisoners of gender, although in highly differentiated but interrelated ways". Sarah White, 1992 notes that in many cases, gender is merely used as a proxy for women. In treating women as an undifferentiated category that is variations of class, ethnicity etc.

\subsection{Gender and Development}

The term Gender and Development (GAD) first introduced in 1970,s decade. It was in the context of the failure of the first decade of development 1961 to 1970 that the relationship between gender and development began to be examined. Ester Boserup's, 1970 in his work "Women's Role in Economic Development" reported that by dismissing or underestimating women's economic contribution many development projects rather than improving the lives of third world women had deprived them of economic opportunities and status. Gender and Development (GAD) represents the socialist feminist approach. Socialist feminists scrutinize the intersection of household and public structures to discover why women are systematically discriminated.

\subsection{Women in Development}

The term Women in Development (WID) gradually emerged Marchand and Parpart 1995:13. Since then, debates on the relationship between women and development have moved on to address new questions and problems, thus giving rise to new labels for identifying one's theoretical position with respect to other previous approaches. The WID discourse, which is closely related to American liberal feminism and modernization theory does not address existing gender structures, but concentrates on technology looks toward incorporating women into conventional projects.

\subsection{Women and Development}

The term "development" is to determine the specific ideas and practices that are associated with a given notion of improvement and to find out the effects to which these ideas and practices are use in a given context. Women and Development (WAD), is a Marxist feminist approach which focuses on women's economic roles and on class and international inequalities. Various authors pointed that the Women in Development (WID) discourse does not fundamentally challenge the notions of 'modernization' or 'development'. But in many ways, this critique applies to Women and Development approach.

\subsection{Religious Fundamentalism}

Marty and Appleby, 1995:6 define fundamentalism is the central substantive similarity among the various movements we identify as fundamentalist is a process of selective retrieval, embellishment, and construction of 'essentials' or 'fundamentals' of a religious tradition for halting the erosion of traditional society and fighting back against the encroachments of secular modernity.

Taslima Nasreen, a writer from Bangladesh, attracted international media attention in the early 1990s after receiving death threats from 'Islamic fundamentalists,' what the world generally came to know about the writer and the country 
that she had to flee was basically the story of a 'female Salman Rushdie' from a 'Third World' country where 'Islamic fundamentalism' was on the rise. "The battle between free expression and Islam still rages," was the opening sentence of a leading article published in The Times (18 June 1994, p.19) in connection to events leading to Taslima Nasreen's flight to the West. The real battle, however, had more to do with different gender ideologies than with 'free expression' or 'Islam' cited to Ainoon Naher, 2005.

\subsection{Dowry}

Dowry demand (Joutuk) has emerged as a major social problem in recent years in Bangladesh. It is not deeply rooted in Bengali Muslim tradition. It comes from Indian Hindu religion culture. The ward dowry means the property that the bride's family gives to the groom during the period of marriage. On the other hand, Bangladeshi laws dowry has been given an extended meaning what is presented whether before or after marriage under demand obligation or pressure as consideration for the marriage that is called dowry. Unemployment is an observable fact of dowry in our society. Although dowry demand is illegal practice persists in the rural communities it exists in the society and gradually increases. Most of the sufferer is poor family. In many cases dowry abuse becomes more severe in nature acid throwing on her face, severely beaten, sometimes murdered her.

\subsection{Acid Violence}

Acid violence is a severe crime in Bangladesh that has been popularized by young generation because of failure to love or refuse of love. Acid throwing on the victim bodies or faces of women became a common means of taking revenge by rejected suitors. It has reached the highest peak in Bangladesh and worldwide incidence of acid violence and acid burns constitute 9 percent of the total burn injuries in the recent years. Acid violence involves throwing acid of women body to disfigure for life. Acid violence is a particularly vicious and damaging form of violence in Bangladesh where acid is thrown in people's faces. The overwhelming majority of the victims are women, and many of them are below 18 years of age. The victims are attacked for many reasons. In some cases it is because a young girl or women has spurned the sexual advances of a male or either she or her parents have rejected a proposal of marriage. Recently, however, there have been acid attacks on children, older women and also men. These attacks are often the result of family and land dispute, dowry demands or a desire for revenge.

In addition to the inevitable psychological trauma, some survivors also face social isolation and ostracism that further damage their self esteem and seriously undermine their professional and personal futures. Women who have survived acid attacks have great difficulty in finding work and, if unmarried as many victims tend have very little chance of ever getting married. In a country like Bangladesh this has serious social and economic consequences.

\subsection{Fatwa}

The word "fatwa" means religious judgments of rural areas in Bangladesh. It is another dimension of violence trials through village elders usually "shalish" or tribunal to settle some local disputes. This traditional custom of excluding women in Bangladesh the rural shalish can be manipulated by the local mullah's religious leaders and the social elite to find women guilty of extramarital sexual affairs. Punishments are meted out with religious laws as interpreted locally in contravention to the existing penal code.

Women empowerment and development is necessary for every sector like political, social, religious, decision making, freedom of choice, access to domestic participation, health care facilities and others sectors in our society. Women development needs a holistic approach. Women should be given maximum chances to get quality education because upcoming generation development depends on women education and educated mother can grantee an educated society. Women needed to be registered in registration center so that they exercise their voting right. Many women do not have their freedom with the family, social, cultural and religious norms and women do not allow taking part in open election. This way they will be encouraged to take part in general election and show their strength also deliver politics better than men.

Women also provided decision making power with all spheres of life especially in house hold there is no place in politics or decision making. Women empowerment, increase their capacity to participate in decision making and leadership quality. Women protection from sexual harassment is essential our society women does not feel safe their homes and outside of work place. They cannot work as free as men. Harassment of women in the national assembly in Bangladesh encouraged women safe work environment, more security should be provided by the government agencies.

National level the annual budget needed to given priority of women social safety net program i.e. education, health, political, family and economic initiatives in order to minimize patriarchal perception. Women environmental hazard protection should be ensuring by the support of rural improvement of poverty related environmental hazard issues. Women health care facilities also needed to increase throughout the life cycle to quality health care strengthen preventive programs that promote women's heath undertake gender sensitive initiatives that address sexually transmitted diseases and promote research. Women media participation increase with expression and decision making through the 
media and promote a balanced and non stereotyped image of women in the media and new technology of communication system.

After Beijing Declaration and Platform for Action, the goals of equality and development for all women are not realized fully. In recent time most of the females are disadvantaged as compared to males in terms of the resources access to utilize in order to perform their tasks, capacity to make their own choices and freedom of life. Another barrier of women development is also necessary for economic progress. The forces which restrict women's employment opportunities constrain half of the population from using its talent and skills for productive sector in Bangladesh.

There are some exclusion of women from political structure and process of multiple structural, functional and personal factors. Women's political participation is a contradictory concept which possesses is the limitations of women's effective participation, empowerment and development. In Bangladesh, particularly my research area women`s are influenced by the existing social norms and values of the culture. Women`s social status also significantly influenced by male dominant cultural ideology and discriminatory social structure. In this regard, this research study primarily aims to investigate social norms how to impediments of women development in Bangladesh. In my research community social structure are run included old customary laws and traditions. The socially constructed reality has been observed as the main source of deprivation. The most physical intensity is a burden of child bearing and rearing which hampered women's access into the job sector as well as the development arena especially women political power hold is highly commercial game which need money.

\section{References}

Aderinwale, A. (1997). Empowering Women for the 21st Century: The Challenges of Politics,

Ahmed, S. M. (2005) Intimate Partner Violence against Women: Experiences from a Woman-focused Development Programme in Matlab, Bangladesh, J Health PopulNutr, 23(1), 95-101, ICDDR, B: Centre for Health and Population Research

Ainoon, N. (2005). Ph.D. Dissertation 'Gender, Religion and Development in Rural Bangladesh' Department of Ethnology South Asia Institute Heidelberg University, Garmany.

Ali, W., Fani, M. I., Afzal, S., \& Yasin G. (2010).Cultural Barriers in Women Empowerment: A Sociological Analysis of Multan, Pakistan. European Journal of Social Sciences, 18(1).

Bari, F. (2005). Women political participation. Issues and challenges, P.4

Bhuiya, A., Sharmin, T., \& Hanifi, S. (2003). Nature of domestic violence against women in a rural area of Bangladesh: Implication for preventive interventions. J Health Pop Nutr, 2, 48-54.

Bhuyia, A., Sharmin, T., \& Hanifi, S. M. A. (2003). Nature of Domestic Violence against Women in a Rural Area of Bangladesh: Implication for Preventive Interventions, J Health Popul Nutr, 21(1), 48-54, ICDDR, B: Centre for Health and Population Research.

Bloom, N., Kretschmer, T., \& Reenen, J. V. (2006). Work-Life Balance, Management Practices and Productivity, Centre for Economic Performance, London School of Economics.

Cagatay, N., \& Erturk, K. (2006).Gender and Globalization: A Macroeconomic Perspective Working Paper No. 19 International Labor Office - Policy Integration Department

Centre for Policy Dialogue. (2009). Domestic Violence in Bangladesh: Cost Estimates and Measures to Address the Attendant Problems, Report no 97, Accessed 2 February, $2012<$ http://cpd.org.bd/pub_attach/DR97.pdf

Commonwealth, S. (1999). Gender Mainstreaming in the Public Service: A Reference Manual for Governments and Other Stakeholders Retrieved on October 22, 2009, from http://www .thecommonwealth.org/gender.

Constitutions of the Peoples Republic of Bangladesh. (Article 27, 28(1), (2)

Eisenstein, Z. (1984). Contemporary Feminist Thought. Unwin, London.

Feldman, S. (2001) 'Exploring Theories of Patriarchy: A perspective from Contemporary Bangladesh' in Signs,26(4), 1097-1127 p 36.

Hadi, S. T. (2009). "It's OK to beat my wife?" - Patriarchal Perceptions of Bangladeshi Respondents and Factors Associated, Bangladesh e-Journal of Sociology, 6(2), 4-14.

Helie-Lucas, Marie-Aimee. (1994). 'The Preferential Symbol for Islamic Identity: Women in Muslim Personal Laws' in V. M. Moghadam(ed) Identity Politics and Women: Cultural Reassertions and Feminisms in International Perspective. Boulder: Westview Press. Pp. 391-407.

Human Rights Watch, 6 July 2011. "Bangladesh: Protect Women Against 'Fatwa' Violence." 
<http://www.hrw.org/news/2011/07/06/bangladesh-protect-women-against-fatwa-violence> [Accessed 15 Aug. 2011]

Islam, K. M. (2007) .Impact of Health Sector Reform on State and Society in Bangladesh. Publishedonline PhD

Thesis.archiv.ub.uniheidelberg.de/volltextserver/volltexte/2007/7862/pdf/Table_of_content_final_with_cover_page. $p d f$

Jahan R. (1994). Hidden danger: women and family violence in Bangladesh. Dhaka: Women for Women; p. 165.

Jahan. (1989). Women and Development in Bangladesh: Challenges and Opportunities. Dhaka: The Ford Foundation.

Kabeer, N. (2003) Gender Mainstreaming in Poverty Eradication and the Millennium Development Canadian International Development Agency, Commonwealth Secretariat, International Development Research Centre

Kabeer. (1994). 'Women's Labour in the Bangladesh Garment Industry: Choices and Constraints' in C Fawzi El-Solh and J Mabro (eds) Muslim Women's Choices: Religious Belief and Social Reality. Oxfor: BERG.

Kandori, M. (1992). "Social Norms and Community Enforcement," Review of Economic Studies, Vol. 59. http://dx.doi.org/10.2307/2297925

Koenig, M. A., Ahmed, S., Hossain, M. B., \& Mozumder, A. B. M. K. A. (2003). Women's Status and Domestic Violence in Rural Bangladesh: Individual and Community Level Effects, Demography, 40, 269-288. http://dx.doi.org/10.1353/dem.2003.0014

Marty, M. E., \& Appleby, R. S. ed. (1995). Fundamentalisms Observed. Chicago: The University of Chicago Press.

Mitra, A. (2003). Establishment Size, Employment, and the Gender Wage Gap, Journal of Socio-conomics, 32(3), 317-330

Moghadam, V. M. (ed) (1994). Identity Politics and Women: Cultural Reassertions and Feminisms in International Perspective. Boulder: Westview Press.

Molyneux, M., \& Razavi, S. (2006). Beijing Plus 10: An Ambivalent Record on Gender Justice, Occasional Papers Series, The United Nations Research Institute for Social Development (UNRISD).

Morrison, A., Ellsberg, M., \& Bott, S. (2007). Addressing Gender-Based Violence: A Critical Review of Interventions, the World Bank Research Observer, Oxford University Press

Naved, R. T., \& Persson, L. A. (2005). Factors Associated with Spousal Physical Violence against Women in Bangladesh. Studies in Family Planning, 36(4), 289-300. http://dx.doi.org/10.1111/j.1728-4465.2005.00071.x

Naz, A., Rehman, H., \& Alam, A. (2011). Gender and Development: Socio-Cultural, Economic, Religious and Political Impediments in Women's Empowerment and Gender Development (A Case Study of Malakand Division KPK, Pakistan) Peshawar University Teachers Association Journal (PUTAJ), 18, 45.

Pisa, E., \& El-Bushra, J. (1992). Gender related violence: its scope and relevance, A paper presented by NAWO to the NAWO/ODA Liaison Group Meeting, 29 October 1992.

Sarho, J. W. (1997). Women and Political Participation in Africa: The Limitations of the Immediate Environment. Empowering Women for the 21st Century: The Challenges of Politics, Business, Development and Leadership Summary Report of the 9th Annual Conference of the Africa Leadership Forum in Accra, Ghana

Schuler, M., (Ed). (1992). Freedom from Violence: Strategies from Around the World, UNIFEM.

Siddiqui, D. M. (2000). 'Miracle Worker or Woman machine? Tracking (Trans) national Realities in Bangladeshi Factories' in Economic and Political Weekly, 27, 12

United Nations Research Institute for Social Development (UNRISD). (2005).Gender Equality: Striving for Justice in an Unequal World UNRISD, Geneva.

White, S. C. (1992). Arguing With the Crocodile Dhaka: University Press Limited.

World Bank. (1995). Toward Gender Equality: The Role of Public Policy, ISBN-13: 978-0-8213-3337-2

World Bank. (2001). Engendering Development Through Gender Equality In Rights, Resources, And Voice Policy Research Report \# 21776

Zaman, H. (1999). Violence against Women in Bangladesh: Issues and Responses, Women's Studies International Forum, 22(1), 37-48. http://dx.doi.org/10.1016/S0277-5395(98)00093-4

\section{(c) $)$ EY}

This work is licensed under a Creative Commons Attribution 3.0 License. 